\title{
Retorika Emha Ainun Nadjib
}

\author{
Rinu Wulan ${ }^{1 *}$, Asep Muhyiddin ${ }^{2}, \&$ Muhamad Khoyin ${ }^{2}$ \\ ${ }^{1} J u r u s a n$ Komunikasi dan Penyiaran Islam, Fakultas Dakwah dan Komunikasi, \\ UIN Sunan Gunung Djati, Bandung \\ 2Jurusan Manajemen Dakwah, Fakultas Dakwah dan Komunikasi, \\ UIN Sunan Gunung Djati, Bandung \\ *Email : rinuwulan19@gmail.com
}

\begin{abstract}
The purpose of this study is to find out how the rhetoric of the figure of intellectual cultural Emha Ainun Nadjib, the method used in this study is a qualitative method with descriptive studies. The results of this study can be obtained that the rhetoric of Emba Ainun Nadjib (Cak Nun) in the Love Indulgence Study in Taman Ismail Marzuki Jakarta Pusat is as follows: 1). Emba Ainun Nadjib was able to maintain the trust of the pilgrims with a simple appearance and real deeds (Ethos), Emha was also able to touch the emotional congregation (pathos) by the way Emha seemed to be what they were, and Emha was able to penetrate the ratio of worshipers by being able to $\log$ God (loghos ) 2). From the style of language used by Emba Ainun Nadjib (Cak. Nun) in each of the studies presented by Emba using parable metas, with the right diction and emphasis in the right up and down of the voice, the material presented can be well received. 3). Emha's influence on the spiritual condition and the way of thinking of the pilgrims is very significant, this is evident from several interviews conducted by researchers towards the congregation.
\end{abstract}

Keywords: rhetoric; Emba; maiyahan

\begin{abstract}
ABSTRAK
Tujuan penelitian ini adalah mengetahui bagaimana retorika sosok budayawan intelektual Emha Ainun Nadjib secara Ethos, Phatos, Loghos, gaya bahasa yang digunakan dan pengaruh Cak Nun terhadap Kondisi spiritual jama'ah. Metode yang digunakan dalam penelitian ini adalah metode kualitatif dengan studi deskriptif. Hasil dari penelitian ini dapat diperoleh bahwa retorika Emha Ainun Nadjib (Cak Nun) dalam Kajian Kenduri Cinta di Taman Ismail Marzuki Jakarta Pusat sebagai berikut : Pertama, Emha Ainun Nadjib mampu menjaga kepercayaan para jamaah dengan penampilan yang sederhana dan perbuatan yang nyata (Ethos), Emha juga mampu menyentuh emosional jamaah (pathos) dengan cara Emha seolah menjadi seperti apa mereka, dan Emha mampu menembus rasio jamaah dengan mampu menglogikakan Tuhan (loghos). Kedua, Dari gaya bahasa yang digunakan oleh Emha Ainun Nadjib (Cak Nun) pada setiap kajian yang disampaikan oleh Emha menggunakan majas perumpamaan, dengan diksi yang
\end{abstract}


tepat dan intonasi penekanan naik turun suara yang tepat, materi yang disampaikan dapat diterima dengan baik. Ketiga, Pengaruh Emha terhadap kondisi spiritual dan cara berpikir jamaah maiyah sangat signifikan, ini terbukti dari beberapa wawancara yang dilakukan oleh peneliti terhadap jama'ah.

Kata Kunci : retorika; Emha; maiyahan

\section{PENDAHULUAN}

We can't not communicate. Kalimat ini benar bahwa kita tidak bisa tidak berkomunikasi. Setiap manusia membutuhkan komunikasi, baik komunikasi verbal maupun non verbal.

Sehari-hari dalam kehidupan kita tidak terlepas dari komunikasi, baik komunikasi dengan Tuhan maupun dengan individu. Kita berkomunikasi sudah sejak dalam kandungan. Bagaimana bisa? Mungkin kita tidak mengingatnya namun ibu kita merasakannya.

Ketika dalam perut seorang ibu bayi didalamnya bergerak dan memberi signal- signal kepada sang ibu, itu merupakan komunikasi yang dilakukan oleh bayi dalam kandungan. Kemudian menurut psikologi bayi didalam kandungan ketika oleh ibunya sering diajak berkomunikasi akan menambah kecerdasaan pada sang bayi berbeda hal dengan sang bayi yang kurang diajak berkomunikasi oleh ibunya.

Komunikasi mempunyai pengaruh yang tinggi, melalui komunikasi pula kita dapat memenuhi kebutuhan emosional kita dan meningkatkan kesehatan mental kita. Melalui komunikasi kita akan mendapat informasi, mengenal rasa cinta, kasih sayang, bahkan iri hati juga benci. Melalui komunikasi kita dapat mempengaruhi dan dipengaruhi orang lain, semua terjadi karena komunikasi, namun tidak setiap orang mempunyai kemampuan untuk berbicara, apalagi berbicara di depan umum, atas dasar ini lah banyak orang yang dengan sungguh-sungguh mempelajari ilmu berbicara atau yang sering disebut dengan retorika.

Retorika atau ilmu berbicara ini digunakan untuk menyatakan kebenaran, berdebat dalam pengadilan, atau berdakwah dijalan Allah swt. Seperti yang kita ketahui dakwah yang berarti menyeru atau mengajak. Satu ayat yang fenomenal dikalangan Fakultas Dakwah dan Komunikasi yaitu surat An-Nahl 125.

Di indonesia orang-orang atau pelaku penyeru kebaikan disebut dengan istilah da'i. Da'i bertugas untuk menyeru kebaikan dan mencegah kebathilan, biasanya para da'i berceramah di masjid-masjid, mungkin sekarang lebih fleksible bahwa dakwah tidak harus di masjid, sekarang sudah ada beberapa da'i yang melaksanakan dakwah tidak hanya di masjid, sebenarnya dakwah bukan tugas da'i namun tugas kita selaku muslim, ini hukumnya fardhu kifayah.

Dalam penyampaian materi ceramah, atau dalam penyampaian ajakanajakannya setiap da'i mempunyai gaya bicara masing-masing, baik dalam pemilihan kata, intonasi, gaya bahasa dan lain sebagainya. Cara penyampaian inilah yang menjadi nilai yang khas bagi seorang da'i.

Tentunya menjadi pembicara tidak mudah, pembicara harus berpikir keras agar dia 
tetap nyaman berbicara di depan dan didengarkan, karena seperti yang kita ketahui bahwa manusia itu lebih cenderung senang berbicara daripada mendengarkan.

Usaha-usaha trik dan trik harus dilakukan bagi seorang pembicara. Dia harus dapat mengemas materi dan mengemas konsep bagaimana cara dia menyampaikan agar pendengar tertarik, tidak bosan, bahkan kecanduan untuk mengikuti atau mendengarkan kajian pembicara.

Atas dasar kebutuhan ini, maka ilmu berbicara atau retorika dipelajari oleh sebagian orang, terlebih lagi untuk mereka yang senang pada dunia public speaking, karena dalam retorika secara detail mempelajari bagaimana penggunaan bahasa, intonasi, mimik wajah, dan hal penting lainnya yang menunjang dalam public speaking.

Retorika juga menarik untuk diteliti, beberapa penelitian terdahulu diantaranya; Desi Dini Endriani 2017 Retorika Motivator, Ilna Siti Rahmawati 2017 Gaya Retorika Ustadz Felix Y. Siaw Melalui Media Youtube, Annisa Puspa Sari 2017 Retorika Ceramah K.H. Muhammad Muhyiddin Abdul Qodir AlMawafi, dan Siti Rosa Farihatul Ain 2017 Retorika Tabligh Buya Yahya.

Retorika setiap pembicara berbeda-beda dan setiap pembicara mempunyai gaya penyampaian dan pemilihan bahasanya masing-masing, jika kita melihat gaya bicara A agym selaku pendakwah berbeda dengan retorika Mario Teguh sebagai motivator, dan berbeda halnya juga dengan retorika sastrawan yang mahir dalam pengelolaan dan pemilihan kata.

Rhetoric dalam bahasa inggris bersumber dari perkataan latin rhetorica yang berarati ilmu berbicara. Cleanth Brooks dan Robert Pen Warren dalam bukunya, Modern rhetoric mendefinisikan retorika sebagai the art of using language affectively atau sebagai seni penggunaan bahasa secara efektif (Effendy, 2003: 53).

Definisi retorika bisa dikatakan sangat kompleks dilihat dari definisi secara historis perkembangan retorika. Menurut Aristoteles (peletak dasar retorika ilmiah dan disebut Bapak retorika), retorika adalah ilmu dan seni yang mengajarkan kepada orang untuk terampil menyusun dan menampilkan tuturan secara efektif untuk memersuasi pihak lain (Muhtadi 2012). Sampai hari ini definisi retorika menurut Aristoteles menjadi acuan definisi baru mengenai retorika.

Aristoteles juga menyebutkan bahwa ada tiga cara untuk mempengaruhi manusia. Pertama anda harus sanggup menunjukan kepada khalayak bahwa anda memiliki pengetahuan yang luas terkait apa yang anda sampaikan, kepribadian yang terpercaya,dan status yang terhormat (ethos). Kedua, anda harus menyentuh hati khalayak : perasaan,emosi, harapan, kebencian, dan kasih sayang mereka (pathos). Ketiga anda meyakinkan khalayak dengan mengajukan bukti. Disini anda mendekati khalayak lewat otaknya (logos) (Rahmat, 2006). Tiga hal ini memang penting dan menjadi acuan ketika berbicara di depan umum.

Retorika berarti kesenian untuk berbicara, baik yang dicapai berdasarkan bakat alam (talenta) maupun kemampuan teknis. Kesenian berbicara ini tidak hanya berarti berbicara tanpa jalan pikiran yang jelas dan tanpa isi, tetapi kemampuan untuk berbicara dan berpidato secara singkat, jelas, padat, dan 
mengesankan (Zaini, 2017: 11).

Titik tolak retorika adalah berbicara. Berbicara berarti mengungkapkan kata atau kalimat kepada seseorang atau sekelompok orang, untuk mencapai suatu tujuan tertentu. Berbicara adalah salah satu kemampuan khusus pada manusia mengungkapkan dan menyampaikan pikirannya kepada manusia lain (wuwur, 1991: 14).

Khalayak bisa percaya dengan apa yang disampaikan ketika kita meyakinkan bahwa kita memiliki pengetahuan yang luas, kita mengetahui banyak hal yang tidak atau belum diketahui khalayak, hal ini bisa terlihat ketika kita berbicara.

Selain pengetahuan yang luas, kepribadian yang terpercaya juga sangat dibutuhkan disini, dalam artian seorang pembicara tidak memiliki riwayat catatan kriminal dalam hidupnya.Karena ketika menjadi pembicara, riwayat hidupnya pasti menjadi salah satu alasan orang untuk melihat, mendengar, dan percaya.

Terakhir, status sosial. Status sosial seorang pembicara sangat penting, ini terlihat dari ketertarikan khalayak untuk ingin mendengarkan atau tidak. Contoh, ketika seseorang berbicara mengenai keagamaan, khalayak akan lebih percaya terhadap ustadz daripada orang biasa. karena khalayak menganggap bahwa seorang ustadz memiliki pengetahuan agama lebih, walau sebenarnya siapa tahu seorang biasa tadi pun berpengatahuan lebih mengenai keagamaan.

Setelah pentingnya pengaruh ethos dalam berbicara, pathos pun tidak terkecuali pentingnya untuk seorang pembicara. Pembicara harus bisa menyentuh hati khalayak, ketika hati seseorang telah tersentuh, maka pembicara akan dengan mudah untuk masuk kedalam hidupnya, seseorang yang telah tersentuh hatinya akan lebih terbuka dan menerima apa yang dikatakan pembicara.

Selain bisa menyentuh hati khalayak, pembicara harus mampu mengontrol dan mengatur tingkat emosional khalayak. Khalayak menjadi bahagia, sedih, bahkan khalayak menjadi mempunyai sebuah harapan untuk suatu hal karena kekuatan dari seorang pembicara.

Bukti-bukti auntentik mengenai apa yang seorang pembicara katakan, menjadi tolak ukur khalayak percaya dan menerima. Khalayak juga membutuhkan bukti dari apa yang dibicarakan pembicara. Apalagi ketika harus berhadapan dengan khalayak yang cukup kritis dalam berpikir. Pendekatan secara otak (logos) sangat diperlukan sebagai seorang pembicara.

Selain definisi menurut Aristoteles, secara terminologi retorika merupakan seni berbicara (Muhtadi, 2012). The art of public speaking begitulah pengertian secara terminology mengenai retorika. Pada akhirnya retorika disebut seni karena dialektika seorang pembicara dalam berbicara baik berpidato, berdebat, berargumen dan lain sebaginya menggunakan tutur bahasa yang baik, menggugah dengan pemilihan kata yang tepat dan sebagainya.

Jika kita memandang berbicara sebagai seni, maka penekanannya diletakan pada penerapan berbicara sebagai alat komunikasi dalam masyarakat (Hoerudin, 2014). Ketika kita memandang berbicara sebagai seni tentunya ada beberapa hal yang mendapat perhatian antara lain, a) berbicara di muka umum ; b) pemahaman 
makna kata ; c) diskusi kelompok ; d) Argumentasi ; e) debat ; f) prosedur parlementer; g) seni drama ; dan i) berbicara melalui udara ;.

Aristoteles, murid Plato yang paling cerdas melanjutkan kajian retorika ilmiah. Ia menulis tiga jilid buku yang berjudul De Arte Rethorica tahap penyusunan pidato: terkenal sebagai Lima Hukum Retorika (The Five Canons of Rhetoric).

Inventio (penemuan).Pada tahap ini, pembicara menggali topic dan meneliti khalayak untuk mengetahui metode persuasi yang paling tepat. Bagi Aristoteles, retorika tidak lain daripada kemampuan untuk menentukan dalam kejadian tertentu dan situasi tertentu, metode persuasi yang ada. Dalam tahap ini juga, pembicara merumuskan tujuan dan mengumpulkan bahan ini juga, pembicara merumuskan tujuan dan mengumpulkan bahan (argumen)yang sesuai dengan kebetulan khalayak.

Aristoteles menyebut tiga cara untuk mempengaruhi manusia. Pertama, anda harus sanggup menunjukkan kepada khalayak bahwa anda memiliki pengetahuan yang luas, keprinbadian yang terpercaya, dan status yang terhormat (ethos). Kedua, anda harus menyentuh hati khalayak, perasaan, emosi, harapan, kebencian dan kasih sayang mereka (pathos). Kelak, para ahli retorika modern menyebutnya imbauan emosional (emotional appeals). Ketiga, anda meyakinkan khalayak dengan mengajukan bukti atau yang kelihatan sebagai bukti. Disini anda mendekati khalayak lewat otaknya (logos).

Disamping ethos, pathos, logos, Aristoteles menyebutkan dua cara lagi yang efektif untuk mempengaruhi pendengar : entimen dan contoh. Entimen (Bahsa Yunani : "en" di dalam dan "thymos" pikiran) adalah sejenis silogaisme yang tidak lengkap, tidak untuk menghasilkan pembuktian ilmiah, tetapi untuk menimbulkan keyakianan. Disebut tidak lengkap, karena sebagian premis dihilangkan.

Menurut Burhan Nurgiyantoro pemajasan (Figure of thought) merupakan teknik pengungkapan bahasa, penggayabahasaan, yang maknanya tidak menunjuk pada makna kata-kata yang mendukungnya, tetapi pada makna yang ditambahkannya, makan yang terkandung didalamnya.

Dengan demikian, pemajasan merupakan gaya bahasa yang memanfaatkan bahasa kiasan. Bahasa kiasan adalah bahasa yang dipakai untuk mengungkapkan sesuatu dengan tidak menunjuk secara langsung, terhadap objek yang dituju.

Gaya bahasa merupakan cara atau teknik mengungkapkan pikiran dan perasaan dalam bentuk lisan maupun tulisan dengan menggunakan bahasa yang khas, sehingga memperlihatkan jiwa dan kepribadian penulis serta menghasilkan pengertian yang jelas dan menarik bagi pembaca.

Akhir-akhir ini yang menarik dalam adalah Retorika budayawan intelektual Emha Ainun Nadjib. Bagaimana tidak? ketika beberapa waktu lalu Organisasi Pergerakan Mahasiswa Islam Indonesia menggelar acara dengan Emha Ainun Nadjib (Cak Nun) sebagai Narasumber di Gedung Aula Anwar Musaddad UIN Sunan Gunung Djati Bandung, acara ini terbilang sukses terlihat dari penuhnya aula oleh para peserta yang antusias mengikuti acara ini.

Buku-buku Emha Ainun Nadjib juga banyak dikonsumsi mahasiswa dan tidak jarang dijadikan bahan untuk diskusi. Sosok Cak Nun yang sangat peduli 
akan budaya ini memiliki ke-Khasan dalam menyampaikan materi.

Kajian Emha Ainun Nadjib yang diselenggarakan hari jum'at 13 oktober 2017 di Plaza Taman Isma’il Marzuki, Jakarta. Kajian ini merupakan kajian rutin perbulan setiap jum'at kedua, kajian ini disebut dengan Kenduri Cinta.

Berdialek dengan para peserta yang hadir dan membahas tema kajian bersamasama, seperti itulah bentuk kajiannya. Berbeda dengan pengajian-pengajian atau kajian-kajian islami pada umumnya.

Peserta yang mengahdiri acara tersebut tidak sedikit, bahkan beberapa orang di luar jawa barat seperti lampung, Ambon, Manado sengaja mengahdiri acara tersebut.

Acara dimulai pukul 20:00 wib s/d 03:00 dini hari, semakin larut orang semakin ramai. Melihat Emha Ainun Nadjib (Cak Nun) begitu mempunyai magnet bagi para jamaah maiyah. Retorika yang digunakan Cak Nun menarik, dan munculah beberapa pertanyaan yaitu, pertama Bagaimana Retorika Emha Ainun Nadjib (Cak Nun) secara Ethos, Phatos, dan Loghos? Kedua, Bagaimana gaya bahasa yang digunakan Emha Ainun Nadjib (Cak Nun) dalam menyampaikan materi ? Ketiga, Bagaimana pengaruh Emha Ainun Nadjib terhadap kondisi spiritual dan cara berpikir jama'ah Kenduri Cinta? Metode yang digunakan dalam penelitian ini yaitu metode kualitatif dengan studi deskriptif, dalam pengumpulan data dilakukan nobservasi, wawancara, dan dokumentasi. Penelitrian dilakukan disalah satu kajian Emha Ainun Nadjib yaitu Kenduri Cinta yang berlokasi di Taman Ismail Marzuki Jakarta Pusat.

\section{HASIL DAN PEMBAHASAN}

Muhammad Ainun Nadjib atau lebih dikenal dengan nama Emha Ainun Nadjib atau lebih akrab disapa Cak Nun merupakan seniman, budayawan intelektual, bahkan seorang kyai ( sekalipun beliau selalu menolak dengan sebutan ini ), lahir dijombang pada Jawa Timur, pada tanggal 27 Mei 1953. Ia merupakan anak keempat dari 15 bersaudara. Ayahnya, Almarhum MA Lathif, adalah seorang petani. Beliau mengenyam pendidikan SD di Jombang (1965) dan SMP Muhammadiyah di Yogyakarta (1968). Beliau juga sempat masuk ke pondok pesantren Gontor Diponorogo namun kemudian pindah dan melanjutkan SMA di SMA Muhammadiyah I sampai dengan selesai. Setelah menamatkan bangku sekolah menengah atas, kemudian Emha Ainun Nadjib (Cak Nun) pernah melanjutkan ke perguruan tinggi Universitas Gajah Mada namun tidak sampai selesai hanya bertahan atu semester.

Awal mula Emha Ainun Nadjib mengadakan maiyahan atau sinaw bareng yaitu 1993 atas gagasan Adil Amrullah adik Emha, maka dari itu diselenggarakanlah pengajian dirumah ibu Emha di Jombang. Pengajian ini diadakan sebagai wadah silaturahmi antara Emha dan keluarganya. Selain itu juga dimaksudkan sebagai respon lingkaran Emha terhadap kondisi masyarakat pada saat itu yang mengalami ketidakpuasan, keputusasaan, amarah terpendam, 
ketidakadilan, singakatnya pada saat itu kondisi masyarakat sudah berada pada tubir semangat penghancuran. Pengajian ini pada awalnya hanya untuk keluarga dan lingkaran Emha saja yang saat itu merasakan kegundahan dihati mereka tentang keadaan hari itu. Lalu kemudian dari keluarga itu meluas menjadi kepada para tetangga, setelah para tetangga mulai meluas kepada satu rt, lalu satu desa, kecamatan, kebupaten, satu provinsi sampai akhirnya meluas sampai di luar jawa timur.

Pengajian tersebut diadakan secara terus menerus sebulan sekali dan mengambil waktu saat bulan purnama, maka pengajian tersebut dinamai pengajian Padhangmbulan. Kemudian usai sejarah besar reformasi di Jakarta dan kejatuhan Soeharto dimulailah pengajian serupa di rumah tinggal Emha Ainun Nadjib, Yogya. Pengajian tersebut dinamai Mocopot Syafaat. Pengajian pengajian rutin ini terus dilakukan, tak sedikit orang berdatangan ke tempat pengajian ini baik di Padhangmbulan maupun pada acara pengajian Mocopot Syafaat. Setelah pengajian-pengajian ini, muncul pula pengajian serupa dengan nama Papperandang Ate di Mandar. Kemudian Haflah Shalawat dan Pengajian Tombo Ati di Surabaya, Gambang Syafaat di Semarang, Obor Illahi di Malang dan Kenduri Cinta di Jakarta.

Dari hasil penelitian, ditemukan beberapa penemuaan dan pembahasan terkait Retorika Emha Ainun Nadjib dari segi Ethos, Pathos, dan Loghos, Gaya Bahasa yang digunakan Emha Ainun Nadjib, dan Pengaruh Emha Ainun Nadjib terhadap Kondisi Spiritual Jama'ah adalah sebagai berikut ;

\section{Retorika Emha Ainun Nadjib dari segi Ethos, Phatos, dan Logos}

Ada tiga komponen penting dalam beretorika yaitu Ethos phatos dan Loghos. Ethos merupakan komponen penting yang harus dimiliki oleh pembicara. Setiap pembicara tentunya mempunyai ethos, namun ada yang baik, tidak begitu baik atau bahkan tidak sama sekali baik. Dari ethos inilah lahir kepercayaan-kepercayaan audiens terhadap pembicara. Kepercayaan dari audience memang harus didapat agar memperlancar proses komunikasi. Ethos meliputi kepercayaan, dan kepribadian pembicara agar dapat mempengaruhi audience.

Ethos yang merupakan kredibilitas sumber (sorce credibility) (Effendy,2006: 60). Ini tidak diragukan lagi untuk sosok Emha Ainun Nadjib, sosok Emha sangat kredibilitas dengan pengetahuan-pengetahuan luas dari segi pendidikan formal maupun ditambah studi hasil literatur

Jika kita pernah mendengar bahwa ketika berbicara mengenai keagamaan, seseorang akan lebih nyaman dan percaya terhadap orang yang berpakaian agamis seperti (menggunakan koko, sarung, peci, dan hal lainnya) dibanding dengan orang yang bergaya biasa saja.

Kenapa hal ini bisa terjadi? Karena kita telah memberi kepercayaan terhadap cara berpakaian seseorang menentukan apa yang dia katakan. Padahal sebenarnya ini tidak menutup kemungkinan bahwa orang yang berpenampilan biasa sajajustru mempunyai pengetahuan lebih.

Uniknya Emha Ainun Nadjib (Cak Nun) beliau secara penampilan fisik 
tidak memakai koko, sarung, peci atau hal lainnya. Beliau menggunakan baju sopan biasa. Emha Ainun Nadjib (Cak Nun) membangun kepercayaan para jamaah melalui karya dan tindakannya, inilah ethos Emha Ainun Nadjib (Cak Nun). Cara Emha Ainun Nadjib berpidato secara orisinil, tidak meniru gaya pidato orang lain.

Phatos dapat diartikan sebagai sentuhan melalui hati, persaan, tingkat emosional, kasih sayang, kebencian dan hal lainnya. Sebagai seo Pahtos menunjukan imbauan emosional (emotional appeals) (Effendy, 2006: 60). Dengan kata-kata sebagai ilistrasi, disertai gaya pengucapan naik turun suara, pengaturan tempo Emha mampu menyentuh perasaan jama'ah.

Pathos yang artinya himbauan emosional, atau sesuatu yang berhubungan dengan emosi manusia, karena saat menyampaikan orasi atau topik permasalahan, seringkali hal tersebut bersangkutan dengan perasaan pendengar dan terkadang menimbulkan banyak empati atau bahkan simpati dari pendengar/audience.

Pembicara haruslah mampu membawa suasana pendengarnya kedalam topik masalah yang diceritakannya, jika respon yang di harapkan muncul. Maka pembicara berhasil memiliki aspek Pathos di dalam dirinya. Hal ini ditunjang pula oleh ketatabahasaan dan gaya bicara yang dimilikinya. Contoh : ketika seorang orator yang menyampaikan aspirasi terhadap pemerintahan di hadapan pendengarnya, orator tersebut menyampaikan kesedihan dan keprihatinan terhadap warga miskin yang semakin terpuruk, jika audience menimbulkan respon simpati saat mendengar cerita tersebut, maka orator berhasil memiliki aspek phatos dalam dirinya sebagai pembicara, seorang pembicara harus mampu menaik-turunkan emosional mereka.

Seorang Emha Ainun Nadjib (Cak Nun) menyentuh hati jamaah maiyah melalui sikap beliau dan cara beliau. Dalam kegiatan maiyahan di Kenduri Cinta panggung didesain memang tidang terlalu tinggi, hanya berjarak setengah meter saja dari bawah. Hal ini memang sengaja Emha Ainun Nadjib minta kepada panitia agar setiap jamaah yang datang merasa lebih dekat dengan Emha Ainun Nadjib.

Disini Emha Ainun Nadjib (Cak Nun) seolah ingin menunjukan bahwa kita sama, tidak ada yang lebih tinggi, tidak ada yang lebih tahu, tidak ada yang lebih apapun. Maiyahan itu adalah kumpulan orang-orang yang haus akan ilmu, haus akan kajian, dan sama-sama merasa orang sesat yang tidak pernah lelah mencari jalan yang benar.

Dari segi desain panggung saja Emha Ainun Nadjib (Cak Nun) mampu menyentuh emosional para jamaah maiyah. Para jamaah merasa lebih dekat dengan Emha Ainun Nadjib (Cak Nun).

Dari cara berpakaian, Emha Ainun Nadjib (Cak Nun) tidak seperti para da'i lainnya, yang mengenakan pakain religi. Cak Nun hanya memakai celana longgar, kemeja sopan dan rapi. Lalu kenapa mendapat kepercayaan? Karena didukung dengan sikap dan karya-karya yang dihasilkan beliau.

Namun justru dengan pakain Emha Ainun Nadjib yang santai namun sopan 
ini malah lebih bisa menyatu dengan jama'ah. Jika kita sering melihat ciri khas dari pengajian-pengajian lain bahwa hal yang paling kontras adalah dari cara berpakaian mereka, hal ini tidak berlaku di kajian Kenduri Cinta. Setiap kalangan dengan enjoy nya bisa masuk kedalam kajian Emha Ainun Nadjib dengan menggunakan baju apa sesuai dengan style nya masing-masing.

Begitu luar biasa nya sosok Cak Nun, tidak heran ketika dalam kegiatan Ma'iyah yang merupakan menurut tulisan-tulisan kecil yang beredar di komunitas maiyah, kata maiyah berasal dari bahasa Arab maiyatublab yang berarti bersama Allah. Kemudian kesandung lidah orang jawa dan akhirnya lebih akrab dengan kata maiyah.Maiyah ini bukan organisasi masyarakat, maiyah lebih dikenal sebagai komitmen nilai bukan bentuk (Saputra, 2012: 79).

Maiyah adalah kajian atau forum belajar bersama (sinow bareng), dalam maiyah tidak mengenal gender, ras, maupun agama, dalam maiyah semua dipandang sama, mungkin hal ini lah yang menjadi salah satu point dari maiyah yang menjadi alasan kenapa orang berbondong-bondong sinaw bareng disini, banyak jama'ah dari luar kota sengaja datang untuk menghadiri sinaw bareng ini atau kajian ini. Orang yang sering mengikuti maiyah disebut jama'ah maiyah. Sebutan ini datang dari mereka sendiri bukan ketentuan oleh Cak Nun maupun panitia maiyah.

Loghos artinya seorang pembicara harus mampu meyakinkan audience dengan pembuktian-pembuktian dari argumen yang disampaikan. Dalam loghos yang dilakukan adalah pendekatan secara otak atau logika. Loghos menunjukan imbauan logis (logical appeals) (Effendy, 2006: 60) yang diketengahkan dalam suatu pidato berdasarkan pemikirann yang mantap. Dimensi ini terlihat mana kali dari Emha Ainun Nadjib menghadapi jamaah yang beragam, seperti mengahadapi jamaah cendekiawan dan lain sebagainya.

Logos memiliki arti Logis, yang dapat di buktikan berdasarkan meteri pembicaraan seorang orator yang memang bersungguh-sungguh, masuk akal, dapat diikuti dan bersifat nyata atau bukan khayalan belaka.

Contoh : saat seorang orator berbicara di hadapan audience, maka yang dibicarakannya haruslah hal yang memadai kenyataannya dan masuk akal. Seperti seorang orator yang memberikan pembahasan mengenai melemahnya harga rupiah di mata dunia. Bukannya pembahasan mengenai 'misalnya' 'andaikan' dan 'coba bayangkan'.

Uraian tersebut adalah landasan utama seorang bagi seseorang untuk dapat berbicara di depan audience, agar apa yang dikatakannya tidak sekedar menjadi angin lalu. Melaikan seorang pembicara haruslah mampu menanamkan pemikiranpemikiran baru terhadap audiencenya

Cara Emha Ainun Nadjib mendekati para jamaah melalui logika nya yaitu dengan pembuktian argumen-argumen yang disampaikan beliau selalu dengan fakta nyata, atau bahkan pengalaman beliau sendiri.

Sosok Emha Ainun Nadjib (Cak Nun) membuat para jamaah selalu berpikir. Emha mampu menglogikakan keberadan Tuhan. Emha tidak membawa Tuhan pada jamaah, namun Emha mampu membawa jamaah maiyah sama-sama menemukan Tuhan. 
Emha mampu menembus rasio para jamaah maiyah, dengan studi literatur dan pengalaman Cak Nun. Dan untuk dedikasi beserta perhatiannya pada kaum arus bawah.

Dari hasil pembahasan diatas, sangat benar apa yang dikatakan Effendy pada bukunya bahwa seorang pembicara harus memiliki ethos, pathos, dan loghos (Effendi, 2003: 60).

\section{Gaya Bahasa Emha Ainun Nadjib (Cak Nun) dalam Penyampaian materi di kajian Kenduri Cinta}

Emha Ainun Nadjib (Cak Nun) dalam setiap materi yang disampaikan selalu mengunakan gaya bahasa baik itu gaya bahsa perbandingan, gaya bahsa sindiran, gaya bahasa penegasan, gaya bahasa pertentangan.

Hal ini bisa dilihat dari setiap pola kalimat yang dikeluarkan Emha Ainun Nadjib (Cak Nun) ketika menyampaikan materi dalam kajian Kenduri Cinta di Taman Ismail Marzuki Jakarta Pusat. Hasil penelitian peneliti, Emha Ainun Nadjib (Cak Nun) sering menggunakan gaya bahasa analogi atau perumpamaan dalam kalimatnya. Berikut beberapa data kalimat yang dikumpulkan peneliti :

(1)“....Ini zaman yang dipenuhi dengan berhala-berhala. Berhala jabatan, berhala popularitas, berhala uang, berhala kekuasaan, berhala likee and dislike, berhala viral dan segala macam bentuk berhala yang memenuhi seantero jagat raya..." Redaksi kenduri Cinta, (jababiroh: 2018).

Dalam kajian nya bulan mei lalu dengan tema "Jababiroh", membahas tentang kepemimpinan dari mulai orde baru, orde lama, sampai reformasi. Dari beberapa kalimat yang disampaikan oleh Emha Ainun Nadjib (Cak Nun) dalam kajian bulan lalu. Seperti kalimat yang dikutip diatas Emha mengambil kata berhala sebagai bahasa perumpamaan.

Seperti yang kita ketahui bahwa berhala adalah suatu benda yang disakralkan kemudian dipuja atau disembah. Itulah pengertian berhala. Nah, disini Emha Ainun Nadjib mengambil kata berahala sebagai perumpamaan. Berhala jabatan bukan berati menyembah jabatan, namun tergila-gila oleh jabatan. Berhala popularitas artinya tergila-gila oleh popularitas. Berhala kekuasaan artinya tergilagila oleh kekuasaan dan lain sebagainya.

(2). "Hari ini kita hidup di era peradaban hutan belantara yang penuh dengan kebebasan. Semua orang bebas melakukan apa saja tanpa mempertimbangkan lagi bahwa segala sesuatunya kelak akan dipertanggungjawabkan. " Redaksi Kenduri Cinta, (Seribu Bayang Prasangka :2018)

Dari data diatas yang diambil dari kalimat Emha Ainun Nadjib dalam kajian maiyahan Kenduri Cinta Bulan April lalu, dengan tema "seribu prasangka" kata huitan belantara menjadi kata perumpamaan. Hal sesungguhnya bukan berati kita hidup di hutan belantara, namun kita seperti di hutan belantara.

(3). "Di dunia pewayangan versi Jawa, Pandhawa Lima juga berhijrah, dan 
itu mereka lakukan pada saat mereka masih sangat muda. Jika Rasulullah berhijrah dari Mekah ke Kota Yatsrib, Pandhawa Lima berhijrah dari Negeri Hastinapura ke Hutan Wanamartha. Puntadewa, Bratasena, Permadi, Pinten dan Tangsen adalah nama muda Pandhawa Lima sebelum berganti nama menjadi Yudhistira, Bima, Arjuna, Nakula dan Sadewa. Padahal nama dewasa Pandhawa yang umum dikenal itu sebenarnya adalah nama-nama Bangsa Jin yang memangku Peradaban Rimba Hutan Wanamartha. " Redaksi Kenduri Cinta, (Ansor Maiyab: 2018).

Dari data diatas, yang diambil dari kajian Emha Ainun Nadjib (Cak Nun) pada bulan Februari dengan tema "Ansor Maiyah", dalam kalimat diatas Emha ingin menjelaskan bahwa pentingnya berhijrah. Salah satu pengertian hijrah yang dikutip dari account official resmi Cak Nun adalah memutuskan hubungan. Dinisi Emha Ainun Nadjib (Cak Nun) ingin menjelaskan bahwa dalam hidup, berhijarah itu penting. Dalam maiyahan sendiri hijrah itu memutuskan hubungan keegoisan individual, ketidak percaya diri, kelemahan mental, ketidak seimbangan dalam berpikir, dan sisi gelap lainnya.

Dalam kalimat diatas, Emha Ainun Nadjib memberi perumpamaan dengan menceritakan bagaimana Rasullullah bahkan cerita pawayangan pun berhijrah.

(4). "Badut-badut dipasang untuk meramaikan pesta demokrasi ini. Para Tim Hore pengais recehan akan semakin bertebaran di media sosial untuk turut meramaikan suasana. Inilah tahun di mana kita akan memasuki hari-hari penuh kepalsuan”. Redaksi Kenduri Cinta, (Amaenangi Zaman Now: 2018.

Dalam kalimat diatas yang dikutip dari kalimat Emha Ainun Nadjib (Cak Nun), dalam kajian kenduri Cinta yang diadakan bulan januari lalu yang dengan tema "Amenangi zaman now".

Badut-badut yang dimaksud bukan badut seperti yang dibayangkan, badut penghibur yang memoles wajah nya dengan bedak tebal dan berpakaian aneh.

Badut disini lebih diartikan kepada sosok yang mengikuti, sorak-sorak akan demokrasi. Bukan badut sebenarnya.

(5). "Kawanan Domba dan Kambing yang tenang merumput, tertib dan teratur tidaklah menjadi pertunjukan yang menarik untuk diberitakan. Indukinduk Domba yang merumput sambil menyusui anak-anaknya nampak tidak menjadi informasi yang layak untuk di-buzzer-kan. Begitupun Komandan Kambing yang menggiring anak-anak Kambing untuk memilah rerumputan yang mudah dikunyah pastinya untuk menjadi berita viral tidaklah mudah. Namun jika ada satu-dua Domba dan Kambing yang bertarung itu bakal menjadi bidikkan publikasi sehingga menjadi trending topic di media sosial. Bahkan sebisa mungkin Domba dan Kambing dibuat bertarung, diprovokasi bagaimanapun caranya supaya mereka berduel satu". Redaksi Kenduri Cinta, (dizaman (Not) Now: 2018).

Kata domba dalam kaliamat diatas bukan domba sungguhan, itu merupakan perumpamaan saja. Hari ini kita melihat di berita bahwa tidak ada berita bagus yang naik di media, bad news is good news. 
Berkat sering mendengar dan melihat berita buruk di media, kejahatan merajalela, menjadikan kita pada hari ini kita khawatir karena hidup di negara yang penuh dengan ancaman bahaya.

Padahal negara kita belum tentu separah apa yang kita pikirkan, banyak prestasi yang ada di negara kita yang semua tertutup oleh berita-berita yang sengaja dinaikan tadi.

Banyak orang-orang berprestasi namun tertimbun dan tak terlihat atau bahkan tersingkir. Disini Emha Ainun Nadjib seakan ingin menunjukan bahwa jangan terlalu khawatir tentang berita yang menakutkan kita, cukup terus lah menanam hal- hal yang baik.

Begitu Elok gaya bahasa yang digunakan oleh Emha Ainun Nadjib (Cak Nun). Dalam kalimat-kalimat yang disampaikan oleh Cak Nun juga terdapat nilainilai keagamaan, seperti nilai tauhid (ketuhanan), nilai ibadah, nilai akhlak, dan lain sebagainya.

Permainan kata yang dilakukan oleh Emha Ainun Nadjib (Cak Nun) sangat rapi. Cak Nun seperti dengan mudah masuk kedalam pikiran melalui kata-kata nya. Aep Kusnawan, dalam bukunya yang berjudul "Teknik Menulis Dakwah" menyatakan bahwa menulis itu penting merupakan benar adanya.

Cak Nun menulis menghasilkan buku, cerpen dan masih banyak lainnya. Dan dari buku ini beliau berdakwah, membagi ilmu dan pengalamannya.

Ketika menulis dianggap penting, ada aktifitas yang saling berkaitan, yaitu membaca. Membaca dan menulis merupakan dua aktifitas yang tidak dapat dipisahkan. Perspektif Al-quran tentang pentingnya tradisi membaca dan menulis (Kusnawan, 2016: 27).

Variasi pemakaian bahasa dipengaruhi oleh situasi pembicaraan, bentuk variasi itu dapat dilihat melalui perwujudan lafal, ejaan, pilihan kata dan tata kalimat. Faktor penting yang berpengaruh terhadap pilihan kata adalah sikap pembicara, yaitu sikap yang berkenaan dengan umur dan kedudukan lawean bicara yang dituju.

Pilihan yang dilakukan Emha Ainun Nadjib tepat, jelas, dan bervariasi. Jelas mudah dimengerti oleh para jamah maiyah yang menjadi sasaran. Pilihan kata dalam pembicaraan sesuai dengan pokok pembicaraan dan dengan siapa berbicara atau berkomunikasi. Komunikasi dapat berjalan lancar dan dapat dipahami oleh jama'ah.

Hali ini sesuai dengan teori dalam buku Pengantar Retorika ( Abidin, 2013: 87) Faktor kebahasaan sangat menunjang keefektifan berbicara seseorang. Faktor ini diantara lain : ketetapan ucapan, penempatan tekanan, nada, durasi yang sesuai, pilihan kata serta kalimat efektif.

\section{Pengaruh Emha Ainun Nadjib terhadap Peningkatan Spiritual dan Cara Berpikir Jama'ah Maiyah}

Pengaruh Emha Ainun Nadjib terhadap peningkatan spiritual dan cara berpikir jama'ah maiyah sangat pekat. Ini terbukti dari hasil wawancara peneliti terhadap 
beberapa jamaah Maiyah yang berasal dari berbagai kalangan, gender, budaya, bahkan agama.

Rata-rata para jamaah merasa bahwa Emha Ainun Nadjib (Cak Nun) mampu mengubah pola pikir mereka. Sosok Emha Ainun Nadjib memang mempunyai magnet tersendiri bagi para jamaah maiyah.

Maka tidak heran diantara mereka banyak yang jauh dari luar pulau berbondong- bondong datang ke maiyahan Kenduri Cinta di Taman Ismail Marzuki Jakarta Pusat. Mereka yakni para jamaah maiyah menemukan ketenangan saat berada dalam kajian tersebut.

Emha Ainun Nadjib tidak membawakan Tuhan dalam kajian, namun Emha Ainun Nadjib mengajak para jamaah untuk sama-sama menemukan keberadaan Tuhan. Emha mampu menunjukan arah menemui Tuhan.

Emha mampu menglogikakan Tuhan sehingga para jamaah bisa memahami itu. Emha membuat hal yang begitu rumit terlihat menjadi sederhana. Emha memberikan arahan-arahan dalam kajian dari beberapa pengalaman yang terjadi dalam kehidupan beliau.

Salah satu mahasiswa semester akhir yang pada malam itu mengikuti kajian, dengan penuh semangat dan berbinar dia bercerita bagaimana dia bisa setiap bulan datang untuk mengikuti kajian dan menjadi candu untuk datang lagi dan lagi. Ketika peneliti menanyai bagaimana hal ini bisa terjadi, jawaban mahasiswa tingkat akhir itu adalah Emha Ainun Nadhjib mampu membantu dia menemukan hal yang tidak dia temukan sebelumnya.

Sebelum menjadi jamaah maiyah, dia merasa tidak terlalu religius. Dia masih anak nongkrong yang hobby nongkrong, bergadang sampai malam dan aktifitas lainnya. Dia bukan sosok yang memang senang dengan pengajian. Namun dia merupakan mahsiswa yang senang membaca, dia membaca beberapa buku hasil karya Cak Nun lalu akhirnya jatuh cinta terhadap tulisan Emha Ainun Nadjib (Cak Nun) itu.

Setelah membaca tulisan Emha Ainun Nadjib (Cak Nun) mahasiswa tingkat akhir salah satu universitas di Jakarta ini penasaran dengan kajian-kajian yang diselenggarakan oleh Emha Ainun Nadjib (Cak Nun), berangkat dari rasa penasaran inilah yang mengantarkan dia pada kajian Kenduri Cinta.

First time sinow bareng, menurutnya adalah hal yang unik dan menakjubkan. Dia malam itu berangkat dari kosan tempat dia tinggal untuk mengikuti kajian. Hari itu dia berangkat sekitar ba'da maghrib atau sekitar jam 18:00 lewat wib. Sesampai di tempat, waktu sudah menujukan pukul isya, namun dia tidak bergegas untuk melakukan sholat isya. Dia diam saja di lokasi menunggu acara dimulai.

Waktu pun berlalu, akhirnya kajian dimulai. Dia berpikir bahwa setiap kajian dalam acara yang berkonten "dakwah" atau kajian keagamaan pasti ada hijab diantara laki-laki dan perempuan. Namun dalam acara kajian maiyahan tidak ada hijab pemisah diantara laki-laki dan perempuan, namun ajaib nya kajian ini berjalan lancar dan aman.

Dia juga melihat bahwa disisi dia ada seorang perempuan yang tidak berjilbab hadir ditengah-tengah jamaah dan mengikuti kajian maiyahan. Dia 
semakin heran, menurut dia ini pertama kalinya dia ikut kajian keislaman yang didalamnya banyak orang beragam.

Selesai dibuat jatuh cinta oleh cara duduk dalam kajian yang tidak ada sekat penghalang antara laki-laki dan perempuan, mahasiswa tingkat akhir inipun dibuat heran kembali saat dalam acara kajian ini di tengah-tengah diskusi ada refreshotak dengan musik-musik jazz dan regae. Dia berpikir lagi, pengajian mana yang dalam kajiannya bisa menampilkan group musik, kalaupun ada tentunya group musik islami seperti (marawis, gambus, dan hal lainnya).

Dia heran, dan kagum tentunya dengan acara kajian tersebut yang menurut dia berbeda dengan acara kajian keislaman lainnya. Setelah mencoba mengikuti maiyahan malam itu, sosok mahsiswa semester akhir ini kecanduan dan akhirnya datang lagi pada bulan selanjutnya.

Tema yang diangkat oleh Emha Ainun Nadjib yang sesuai kebutuhan, dan disampaikan secara ringan mampu menjadi daya tarik untuk kecanduan dengan kajian maiyahan.

Sekali ikut kajian, dua kali, tiga kali bahkan juli ini merupakan tahun kedua dia mengikuti kajian Kenduri Cinta. Menurut dia, disadari atau tidak, setelah mengikuti kajian maiyahan pola pikir dia pada suatu hal sedikit berubah dia mengatakan bahwa hari ini dia lebih merasa berbeda saja dari sebelumnya. Kalau dikatakan lebih tasawuf atau sufi mungkin bisa jadi, walau menurutnya belum setasawuf Emha Ainun Nadjib (Cak Nun).

Selain mahsiswa, peneliti juga mewawancarai jamaah dari profesi lain. Dia sekitar berumur 30 tahunan, seorang karyawan disalah satu perusahaan yang ada di Bandung. ketika diwawancara dia sudah cukup lama mengikuti kajian maiyahan sekitar lima tahun terakhir.

Terlintas dipikaran peneliti bahwa bagaimana bisa seorang karyawan yang mempunyai pekerjaan cukup melelahkan setiap hari nya, karena dia harus bekerja dari pukul 06:00 pagi sampai 18:00 sore setiap harinya belum ditambah kerja lembur namun masih sempat ikut maiyahan?

Jawaban yang mengejutkan datang dari karyawan tersebut, dia menjawab bahwa maiyahan adalah obat dari lelah jiwanya. Di maiyahan ketanangan, keikhlasan, kesabaran tercipta untuknya.

Semenjak menjadi jamaah maiyah, dia sadar bahwa dia sudah cukup lelah dengan pekerjaannya namun mungkin saja diluar ada orang yang bahkan lebih lelah mencari pekerjaan. Dia sudah bekerja, dan dia syukuri pekerjaannya. Sebelumnya, dia juga sering mengeluh tentang dia yang harus bekerja sepanjang hari. Berlelahlelah dengan pekerjaan, melawan polusi di jalan dengan bermacet- macetan, dan ketika pulang ke rumah jangankan ingin beibadah, dia sudah sangat lelah dan ingin beristirahat.

Dia sekali ikut kajian Emha Anun Nadjib (Cak Nun) dibawa oleh temannya, cara berpikirnya tidak langsung berubah hanya saja dia sedikit sudah lebih paham mengenai bagaimana dia harus berpikir.

Sampai akhirnya disuatu kajian maiyahan dia bersedih dan merasa bahwa 
selama ini dia rugi jika tidak beribadah kepada Allah, dia sangat lelah di dunia dengan pekerjaannya dia tidak ingin lelah di akhirat. Emha Ainun Nadjib (Cak Nun), mengantarkan dia sampai pada pemikiran seperti ini.

Selain mahasiswa, dan karyawan, peneliti juga mewawancarai jamaah dari profesi dan gender lainnya. Seorang perempuan berparas cantik terlihat masih muda, dengan rambut sebahu dan kulit yang putih. Ketika diwawancarai, dia seorang penyanyi di cafe-cafe, dia menjelaskan mengapa hari itu dia datang ke acara kajian Emha Ainun Nadjib (Cak Nun).

semenjak sinow bareng di acara kajian Kenduri Cinta dia merasa bahwa Allah memberi kesempatan pada siapa saja yang ingin belajar, ingin berubah, dan ingin menjadi lebih baik.

Menurutnya, setiap orang punya tingkatan untuk memahami, mengerjakan apa yang dia lakukan. Dan untuk mencapai kesempurnaan dalam beribadah adalah proses. Dan kajian ini merupakan salah satu proses pembelajaran untuk dia menjadi lebih baik, begitulah tuturnya kurang lebih saat ditemui dikajian kenduri Cinta.

Jama'ah maiyahan kenduri Cinta sangat beragam dari mulai mahasiswa, pekerja, pengusaha, bahkan pengangguran juga ada disana. Dari setiap wawancara dengan menggunakan sample dari semua gender jawaban mereka hampir sama, yaitu kajian maiyahan Kenduri Cinta mampu membawa mereka pada tingkat religius yang lebih tinggi dan merubah cara berpikir mereka.

Mereka merasa bahwa dengan sinow bareng disana, mereka menemukan rasa ketenangan. Disana Emha seolah menjelaskan bahwa mereka yang berada dalam kajian maiyahan Kenduri Cinta tidak ada yang paling pintar, paling tahu, paling paling baik dan paling tinggi. Emha menganggap bahwa mereka semua sama, begitu pun dengan Emha. Sama-sama saling belajar dan saling membutuhkan.

Jama'ah maiyah merasa dengan Emha mereka menemukan harapan kebaikan, setiap orang seakan mempunyai kesempatan untuk menjadi lebih baik. Dan setiap orang berhak untuk itu. Emha mampu memecahkan apa yang selama ini tidak terpecahkan oleh mereka.

Mereka mendapatkan pencerahan setelah mengikuti kajian, dalam teori spiritual dijelaskan bahwa "Spiritual merupakan kebangkitan atau pencerahan diri dalam mencapai tujuan dan makna hidup, spiritualisme merupakan bagian dari kesehatan dan kesejahteraan seseorang" (Hasan, 2006: 288).

\section{PENUTUP}

Setelah dilakukan penelitian, ada beberapa point penting yang didapatkan dari penelitian juga beberapa saran untuk keberlangsungan peneliti-peneliti selanjutnya diantaranya ; Pertama, Emha Ainun Nadjib mempunyai Ethos, Pathos, dan Logos yang sangat baik. Dari segi Ethos, beliau mampu menarik jamaah dan memupuk kepercayaan mereka dengan karya nyata dan perbuatan, Emha Ainun Nadjib (cak Nun) mempunyai kredibilitas tinggi, sehingga masyarakat atau para jama'ah maiyah bisa dengan mudah percaya terhadap sosok nya ini, Emha juga telah 
membuktikan dengan berbagai karya yang dihasilkan oleh beliau, disamping itu Emha Ainun Nadjib juga mampu menyentuh emosional para jamaah maiyah dengan selalu memposisikan bahwa Emha Ainun Nadjib (Cak Nun) adalah siapa mereka, Emha menjadi sosok pergerakan kalangan bawah, pemerhati sisi kehidupan orang yang sering terabaikan, selain mempunyai ethos dan pathos Emha Ainun Najib mampu menembus rasio para jamaah maiyah, Emha Ainun Nadjib mampu menglogikakan Tuhan.

Kedua, Emha Ainun Nadjib memiliki gaya bahasa yang khas dalam setiap materi yang beliau sampaikan. Beliau selalu menggunakan majas perumpamaan. Perumpamaan ini digunakan Emha Ainun Nadjib agar setiap jamaah mampu membayangkan masalah yang terjadi. Emha Ainun Nadjib (Cak Nun) selalu memberi perumpamaan-perumpamaan yang sederhana sehingga para jamaah maiyah paham akan makna nya.

Ketiga, melihat sosok Emha Ainun Nadjib (Cak Nun) yang sangat karismatik ini, tentunya menjadi pengaruh terhadap jamaah maiyah. Terutama dalam peningkatan spritual dan cara berpikir jamaah. Dengan keahlian sosok Emha Ainun Nadjib yang mampu menjadikan hal yang sulit dipandang menjadi sederhana, tidak sedikit jamaah yang terkagum dan mengikuti pola pikir Emha. Setiap da'i harus mempunyai ethos, pathos, dan loghos. Dengan ethos artinya mendapat kepercayaan dari mad'u, kepercayaan ini dapat diperoleh dari pengetahuan yang luas, dari karya-karya yang dibuat ataupun dari jabatan yang didapat. Pathos, artinya da'i mampu menyentuh emosional mad'u sedangkan loghos yaitu seorang da'i harus mampu memberikan contoh dan bukti-bukti yang real terhadap jamaah.

Dari hasil penelitian terhadap Emha Ainun Nadjib (Cak Nun) terdapat bebrapa acuan atau dapat bmenjadi saran terhadap seoreang penel;iti maupun seorang da'i kedepannya bahwa;

pertama, menjadi seorang da'i diperlukan menguasai gaya bahasa dan pemilihan kata yang tepat. Karena bahasa mampu menjadi daya tarik untuk persuasif.

Kedua, seorang $d a^{\prime} i$ dikatakan sukses dalam berdakwah ketika menghasilkan efek yang cukup signifikan. Seorang $d a^{\prime} i$ diharuskan membawa efek atau pengaruh terhadapa peningkatan spiritual mad'u atau cara berpikir mad'u

Ketiga, sebagai seorang da'i kita harus mempunyai kredibilitas yang tinggi agar dapat memupuk kepercayaan para jama'ah, tentu ini tidak mudah, maka dari itu teruslah berproses dengan baik.

Keempat, seorang da'i harus peka terhadap lingkungan sekitar. Hari ini, kita harus bisa menjadi solusi keluhan-keluhan masyarakat, kita haru sbisa mengangkat satu masalah menjadi tema yang menarik dan tidak monoton.

\section{DAFTAR PUSTAKA}

Abidin, Y. Z. (2013). Pengantar Retorika. Pustaka Setia. 
Ain, S. R. F. (20017). Retorika Tabligh Buya Yabya. Skripsi. Universitas Islam Negeri Sunan Gunung Djati Bandung.

Effendy, O. O. (2006). Ilmu komunikasi teori dan praktek. Remaja Rosda Karya.

Endriani, D. D. (2017). Retorika Motivator. Skripsi. Universitas Islam Negeri Sunan Gunung Djati Bandung.

Hendrik, D. W. (1991). Terampil berpidato berargumentasi bernegosiasi. Kanisius

Hoerudin, W. C. (2014). Mata kuliah umum pengembangan karakter Bahasa Indonesia, Bandung . CV Semiotika.

Kusnawan, A. (2016). Teknik Menulis Dakwah. Simbiosa Rekatama Media.

Muhtadi, A. S. 2012. Komunikasi Dakwah Teori, Pendekatan, dan Aplikasi. Simbiosa Rekatama Media

Rahmawati, S. I. (2017). Gaya Retorika Dakwah Ustadz Felix Y. Siaw Melalui Media Youtube. Universitas Islam Negeri Sunan Gunung Djati Bandung.

Redaksi Kenduri Cinta. (2017). Dizaman (Not) Now. Diakses 07 Desember 2017 dari, http:/ / Caknun.Com

Redaksi Kenduri Cinta. (2018). Amenangi Zaman Now. Diakses 09 Januari 2018 dari, http:/ / Caknun.Com

Redaksi Kenduri Cinta. (2018). Ansor Maiyah. Diakses 08 Februari 2018 dari, http:/ / Caknun.Com

Redaksi Kenduri Cinta. (2018). Seribu Bayang Prasangka. Diakses 11 April 2018 dari, http:/ / kenduricinta.com

Redaksi Kenduri Cinta. (2018). Jababiroh. Diakses 15 Mei 2018 dari, http :/ / kenduricinta.com

Sari, P. A. (2017). Retorika Ceramab K.H Mubammad Mubyiddin (Abdul Qodir Almanafi). Universitas Islam Negeri Sunan Gunung Djati Bandung.

Saputra, P. (2012). Spiritual Jurney pemikiran dan perenungan Emba Ainun Nadjib. PT KOMPAS media nusantara.

Zaini, A. (2017). Retorika Dakwah Mama Dedeh dalam acara "Mama \& Aa Beraksi" di Indosiar. dalam Ilmu dakwah : Academi Journal for Homiletic Studies. 4(14). 219-234. 
R. Wulan, A. Muhyiddin, \& M. Khoyin 